\title{
Magnetohidrodinamik Tak Tunak Pada Konveksi Campuran Yang Mengalir Melalui Bola Teriris Dalam Fluida Kental Di Bawah Pengaruh Medan Magnet
}

\author{
Mochamad Satria Dharma Utama, Basuki Widodo, dan Dieky Adzkiya \\ Departemen Matematika, Fakultas Matematika Komputasi dan Sains Data, Institut Teknologi Sepuluh Nopember \\ (ITS) \\ e-mail:b_widodo@matematika.its.ac.id, dieky@matematika.its.ac.id
}

\begin{abstract}
Abstrak-Magnetohidrodinamik (MHD) adalah studi mengenai dinamika fluida konduksi listrik akibat medan magnet. Pada penelitian ini diamati permasalahan tentang aliran fluida kental yang mengaliri bola teriris bermagnet dengan alirannya dipengaruhi konveksi campuran dengan berfokus pada kondisi tak tunak. Aliran fluida kental yang melewati bola teriris akan membentuk lapisan batas. Berdasarkan fenomena pada lapisan batas tersebut dibentuk Persamaan Pembangun dari model matematika, Persamaan Pembangun berdimensi ditransformasikan ke dalam bentuk non-dimensional selanjutnya ditransformasikan ke dalam bentuk Persamaan Similaritas. Kemudian, Persamaan Similiritas tersebut diselesaikan secara numerik dengan metode Keller-Box. Setelah itu, dikaji tentang perbandingan parameter yang digunakan yaitu parameter magnetik, parameter konveksi, dan besar sudut irisan bola terhadap kurva kecepatan dan temperatur dengan cara mengembangkan model matematika dari permasalahan di atas dan menyelesaikan secara numerik menggunakan metode KellerBox. Hasil dari penelitian ini, model matematika yang didapatkan melalui persamaan-persamaan sebelumnya, jika semakin besar parameter magnetik, parameter konveksi dan sudut irisan, maka semakin meningkat pula kecepatan aliran fluida. S ehingga variasi parameter tersebut berbanding lurus dengan kecepatan fluida. Selain itu, jika semakin besar parameter magnetik, parameter konveksi dan sudut irisan, maka semakin berkurang pula temperatur fluida. Sehingga parameter tersebut berbanding terbalik dengan temperatur fluida. Namun pada simulasi temperatur Bilangan Prandtl berlaku sebaliknya. Bilangan Prandtl berbanding lurus dengan temperatur fluida dan berbanding terbalik terhadap kecepatan fluida. Hasil dari setiap simulasi menunjukkan bahwa setiap kurva dari setiap simulasi parameter akan berubah secara signifikan pada setiap perubahan jarak titik penelitan atau jarak lapisan batas.
\end{abstract}

Kata Kunci-Bola pejal teriris, Fluida Kental, Konveksi Campuran, Magnetohidrodinamik, Metode Keller-Box.

\section{PENDAHULUAN}

A LIRAN magnetohidrodinamik atau A Magnetohydrodynamic Flow (MHD) adalah salah satu aliran khusus yang cukup sering diteliti beberapa tahun ini. Aliran Magnetohidrodinamik mempelajari aliran fluida yang dapat menghantarkan aliran listrik dan dipengaruhioleh medan magnet [1]. Pada bidang teknologi, pemanfaatan magnetohidrodinamik cukup luas. Salah satunya adalah pada PLTU [2]. Medan magnet juga dapat digunakan untuk mengendalikan operasi aliran seperti di mana cairan keluar mengandung listrik dan terionisasi [3].

Dalam hal ini aliran fluida kental dipengaruhi oleh medan magnet dan aliran konveksi. Medan magnet disekitar fluida akan merubah kecepatan fluida. Konveksi merubah temperatur aliran fluida kental yang melewati permukaan bola teriris karena adanya gaya luar yang mempengaruhi perpindahan panas. Permukaan irisan bola mempengaruhi kecepatan dan suhu aliran fluida. Variasi sudut iris an bola juga mempengaruhi kecepatan fluida. Penelitian sebelumnya mengenai magnetohidrodinamik fluida kental tak tunak dengan konveksi paksa yang mengalir melewati bola teriris diteliti menggunakn berbagai parameter [4].

Dalam penelitian ini, digunakan beberapa tinjauan pustaka mengenai magnetohidrodinamik mulai dari jenis konveksi, jenis fluida, dan lainnya [5], selain itu konveksi bebas juga pernah diteliti [6]. Hasil simulasi numerik aliran magnetohidrodinamik tak tunak pada konveksi paksa menggunakan metode Keller-Box menunjukkan bahwa ketika parameter magnetik bertambah maka distribusi temperatur fluida berkurang dan ketika parameter magnetik berkurang maka distribusi kecepatan fluida juga berkurang [7]. Selain itu, kecepatan akan semakin bertambah seiring bertambahnya medan magnet [8]. Dan juga bertambahnya parameter magnetik maka profil kecepatan semakin bertambah pada fluida micropolar [9].

Dalam penelitian ini akan diselidiki pengaruh adanya parameter magnetik, parameter konveksi, dan besarsudut irisan bola terhadap kurva kecepatan dan temperatur fluid. Penelitian ini juga akan dikaji secara teoritik dan numerik pengaruh medan magnet dan perpindahan panas dengan konveksi paksa pada fluida pekat, apabila melewati sebuah benda yang berbentuk bola teriris dibawah pengaruh koveksi campuran. Bola yang diiris adalah bola pejal dengan permukaan halus (tidak berpori).

\section{METODOLOGI PENELITIAN}

Tahapan penelitian yang dijabarkan disini akan memperjelas apa saja yang dilakukan dalam menyelesaikan permasalahan pada penelitian ini. Secara detail, desain dan metode penelitian ini dapat diuraikan sebagai berikut: 
1. Mengkaji model matematika aliran fluida dan perpindahan panas tak tunak pada lapisan batas magnetohidrodinamik aliran fluida kental yang melalui bola teriris .

2. Mengkaji model matematika aliran fluida dan perpindahan panas tak tunak pada lapisan batas magnetohidrodinamik aliran fluida kental yang melalui bola teriris dibawah pengaruh medan magnet.

3. Mengembangkan model aliran fluida dan perpindahan panas tak tunak pada lapisan batas magnetohidrodinamik aliran fluida kental yang melalui bola teriris dibawah pengaruh medan magnet menggunakan continuum principle dan hukum-hukum fisika.

4. Mengembangkan metode beda hingga implisit dengan metode Keller-Box untuk penyelesaian model matematika dari aliran fluida dan perpindahan panas tak tunak pada lapisan batas magnetohidrodinamik aliran fluida kental yang melalui bola teriris dibawah pengaruh medan magnet.

5. Membuat algoritma program. Pada tahapan ini, akan dibuat algoritma program dari penyelesaian metode beda hingga implisit dengan skema Keller-Box

6. Membuat program simulasi hasil.

\section{ANALISIS DAN PEMBAHASAN}

\section{A. Persamaan Pembangun}

Persamaan pembangun yang digunakan pada fluida yang bersifat unsteady dan incompressible adalah s ebagaiberikut Persamaan Kontinuitas

$$
\begin{array}{cc} 
& \nabla \cdot \boldsymbol{u}=\mathbf{0} \\
\frac{\partial(\bar{r} \bar{u})}{\partial \bar{x}}+\frac{\partial(\bar{r} \bar{v})}{\partial \bar{y}}=0 & \\
\text { Persamaan Energi } & \\
\rho \mathrm{C}_{\mathrm{p}}\left(\frac{\partial \mathrm{T}}{\partial \mathrm{t}}+\mathrm{u} \frac{\partial T}{\partial x}+\mathrm{v} \frac{\partial T}{\partial y}\right)=\mathrm{c}\left(\frac{\partial^{2} T}{\partial x^{2}}+\frac{\partial^{2} T}{\partial y^{2}}\right)
\end{array}
$$

Persamaan momentum

$$
\begin{aligned}
& \int \rho\left(\left(\frac{\partial \boldsymbol{u}}{\partial t}\right)+(\boldsymbol{u} \cdot \nabla \boldsymbol{u})\right) d \forall= \\
& \int\left(-\nabla p+\mu \nabla^{2} \boldsymbol{u}\right) d \forall+\int-\sigma \frac{25}{16} \mathrm{~B}_{0}^{2} \boldsymbol{u} d \forall+\left(\rho-\rho_{\infty}\right) \boldsymbol{g} \\
& \text { dengan } \bar{r}(\bar{x})=\bar{b} \sin \frac{\bar{x}}{\bar{b}}
\end{aligned}
$$

Dimana variabel yang menggunakan tanda ${ }^{-}$menunjukan bahwa variabel tersebut merupakan variabel berdimensi.

\section{B. Persamaan Momentum}

Pada kasus ini sumbu $-z$ diabaikan. Sehingga persamaan momentum yang ada dapat dibangun cukup pada sumbu $-x$ dan sumbu $-y$. Pada Persamaan momentum (3) terdapat komponen vektor, yang apabila dijabarkan dan dengan mengelompokkan vektor $\hat{\imath}$ untuk sumbu $x$ dan vektor $\hat{\jmath}$ untuksumbu y didapatkan persamaan momentum pada sumbu $x$

$$
\begin{aligned}
& \rho\left(\frac{\partial \bar{u}}{\partial \bar{t}}+\bar{u} \frac{\partial \bar{u}}{\partial \bar{x}}+\bar{v} \frac{\partial \bar{u}}{\partial \bar{y}}\right)= \\
& -\frac{\partial p}{\partial \bar{x}}+\mu\left(\frac{\partial^{2} \bar{u}}{\partial \bar{x}^{2}}+\frac{\partial^{2} \bar{u}}{\partial \bar{y}^{2}}\right)-\frac{25}{16} \sigma \mathrm{B}_{0}{ }^{2} \bar{u}+\left(\rho-\rho_{\infty}\right) g_{x}
\end{aligned}
$$

Dan untukpersamaan momentum pada sumbu $y$

$$
\begin{aligned}
& \rho\left(\frac{\partial \bar{v}}{\partial \bar{t}}+\bar{u} \frac{\partial \bar{v}}{\partial \bar{x}}+\bar{v} \frac{\partial \bar{v}}{\partial \bar{y}}\right)= \\
& -\frac{\partial p}{\partial \bar{y}}+\mu\left(\frac{\partial^{2} \bar{v}}{\partial \bar{x}^{2}}+\frac{\partial^{2} \bar{v}}{\partial \bar{y}^{2}}\right)-\frac{25}{16} \sigma \mathrm{B}_{0}{ }^{2} \bar{v}+\left(\rho-\rho_{\infty}\right) g_{y}
\end{aligned}
$$

Pendekatan Boussinesq digunakan untuk mendekati perbedaan kerapatan yang menyebabkan adanya aliran akibat dari interaksi antara gaya gravitasi dan tekanan hidrostatis seperti pengaruh temperatur. Berdasarkan pendekatan Deret Taylor, yaitu

$\frac{\rho_{\infty}}{\rho}=1+\beta\left(\bar{T}-T_{\infty}\right)+O\left(\bar{T}-T_{\infty}\right)^{2}$

Diasumsikan bahwa nilai $\left(\bar{T}-T_{\infty}\right)$ kecil sehingga bagian yang berorder tinggi dapat dihilangkan, maka persamaannya dapat diubah menjadi

$$
\rho-\rho_{\infty}=-\rho \beta\left(\bar{T}-T_{\infty}\right)
$$

Dengan $\beta$ adalah koefisien ekspansi panas yang dapat dinyatakan dengan

$\beta=-\frac{1}{\rho}\left(\frac{\partial \rho}{\partial \bar{T}}\right)_{p}$

Selanjutnya dengan mensubtitusikan persamaan (6) pada persamaan momentum sumbu- $x$ dan sumbu-y yang ditunjukan pada persamaan (4) dan (5), persamaan momentumnya menjadi

$$
\begin{aligned}
& \rho\left(\frac{\partial \bar{u}}{\partial \bar{t}}+\bar{u} \frac{\partial \bar{u}}{\partial \bar{x}}+\bar{v} \frac{\partial \bar{u}}{\partial \bar{y}}\right)= \\
& -\frac{\partial p}{\partial \bar{x}}+\mu\left(\frac{\partial^{2} \bar{u}}{\partial \bar{x}^{2}}+\frac{\partial^{2} \bar{u}}{\partial \bar{y}^{2}}\right)-\frac{25}{16} \sigma \mathrm{B}_{0}{ }^{2} \bar{u}+\rho \beta\left(\bar{T}-T_{\infty}\right) g_{x}
\end{aligned}
$$

pada sumbu $-x$ dan pada sumbu $-y$ dapat dituliskan menjadi

$$
\begin{aligned}
& \rho\left(\frac{\partial \bar{v}}{\partial \bar{t}}+\bar{u} \frac{\partial \bar{v}}{\partial \bar{x}}+\bar{v} \frac{\partial \bar{v}}{\partial \bar{y}}\right)= \\
& -\frac{\partial \bar{p}}{\partial \bar{y}}+\mu\left(\frac{\partial^{2} \bar{v}}{\partial \bar{x}^{2}}+\frac{\partial^{2} \bar{v}}{\partial \bar{y}^{2}}\right)-\frac{25}{16} \sigma \mathrm{B}_{0}{ }^{2} \bar{v}+\rho \beta\left(\bar{T}-T_{\infty}\right) g_{y}
\end{aligned}
$$

Pada penelitian ini menggunakan kondisi batas yaitu

$\bar{t}<0: \bar{u}=\bar{v}=0, \bar{T}=T_{\infty}$ untuk setiap $\bar{x}, \bar{y}$

$\bar{t} \geq 0: \bar{u}=\bar{v}=0, \bar{T}=T_{w}$ untuk setiap $\bar{y}=0$

$$
\bar{u}=\bar{u}_{e}(\bar{x}), \bar{T}=T_{\infty} \text { saat } \bar{y} \rightarrow \infty
$$

Dengan kecepatan aliran bebas $\bar{u}_{e}=\frac{3}{2} \sin \left(\frac{\bar{x}}{\bar{b}}\right)$

\section{Transformasi Variabel Tak Berdimensi}

Variabel tak berdimensi digunakan untuk mempermudah proses komputasi. Pada permasalahan ini variable tak berdimensi yang digunakan adalah sebagai berikut[6]

$$
\begin{array}{ll}
x=\frac{\bar{x}}{a}, \quad y=R e^{1 / 2} \frac{\bar{y}}{a}, \quad r=\frac{\bar{r}}{a}, \quad b=\frac{\bar{b}}{a} \\
u=\frac{\bar{u}}{U_{\infty}}, \quad v=R e^{1 / 2} \frac{\bar{v}}{U_{\infty}} \\
t=\frac{U_{\infty} \bar{t}}{a} \\
p=\frac{\bar{p}}{\rho U_{\infty}^{2}}, \quad T=\frac{\bar{T}-T_{\infty}}{T_{w}-T_{\infty}}
\end{array}
$$

Dengan $R e=\frac{U_{\infty} a}{v}$ dan $v$ adalah viskositas kinematik yang dapat dituliskan sebagai $v=\frac{\mu}{\rho}$. Ditambahkan pula parameterparameter yang didefinisikan sebagaiberikut:

Parameter Magnetik(M)

$$
M=\frac{\sigma B_{0}^{2} a}{\rho U_{\infty}}
$$

Parameter Konveksi $(\alpha)$

$$
\alpha=\frac{G r}{R e^{2}}
$$

Bilangan Grashof (Gr)

Bilangan Prandtl $(P r)$

$$
\begin{aligned}
& G r=\frac{g \beta\left(T_{w}-T_{\infty}\right) a^{3}}{v} \\
& \operatorname{Pr}=\frac{v \rho C_{p}}{c}
\end{aligned}
$$




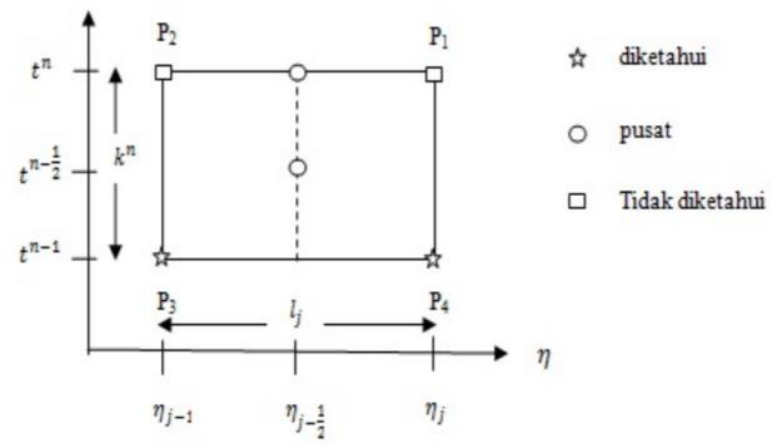

Gambar 1. Gambar Stensil Beda Hingga.

Selanjutnya dilakukan subtitusi variabel-variabel tak berdimensi (9) dan parameter (10) pada Persamaan (1), (2), (7) dan (8) sehingga didapatkan Persamaan Kontinuitas

$$
\frac{\partial(r u)}{\partial x}+\frac{\partial(r v)}{\partial y}=0
$$

Persamaan Momentum sumbu- $x$

$$
\begin{aligned}
& \frac{\partial u}{\partial t}+u \frac{\partial u}{\partial x}+v \frac{\partial u}{\partial y}= \\
& -\frac{\partial p}{\partial x}+\frac{1}{R e}\left(\frac{\partial^{2} u}{\partial x^{2}}+\frac{1}{R e^{-1}} \frac{\partial^{2} u}{\partial y^{2}}\right)-\frac{25}{16} M u+\alpha T \tan \left(\frac{x \cos x}{\cos \theta_{s}}\right)
\end{aligned}
$$

Persamaan Momentum sumbu-y

$$
\begin{aligned}
& \frac{1}{R e}\left(\frac{\partial u}{\partial t}+u \frac{\partial u}{\partial \mathrm{x}}+v \frac{\partial u}{\partial y}\right)= \\
& -\frac{\partial p}{\partial y}+\frac{1}{R e^{2}} \frac{\partial^{2} v}{\partial x^{2}}+\frac{1}{R e} \frac{\partial^{2} v}{\partial y^{2}}-\frac{25}{16} \frac{M}{R e} v+\frac{\alpha T}{R e^{\frac{1}{2}} \cos \left(\frac{x \cos x}{\cos \theta_{s}}\right)}
\end{aligned}
$$

Persamaan Energi

$$
\left(\frac{\partial T}{\partial t}+u \frac{\partial T}{\partial x}+v \frac{\partial T}{\partial y}\right)=\frac{1}{R e \operatorname{Pr}} \frac{\partial^{2} T}{\partial x^{2}}+\frac{1}{\operatorname{Pr}} \frac{\partial^{2} T}{\partial y^{2}}
$$

\section{Pendekatan Lapisan Batas}

Digunakan pendekatan lapisan batas dengan $R e \rightarrow \infty$ sehingga $\frac{1}{R e} \rightarrow 0$, maka diperoleh

Persamaan Kontinuitas

$$
\frac{\partial(r u)}{\partial x}+\frac{\partial(r v)}{\partial y}=0
$$

Persamaan Momentum sumbu- $x$

$$
\begin{aligned}
\frac{\partial u}{\partial t}+u \frac{\partial u}{\partial x}+ & v \frac{\partial u}{\partial y}= \\
& -\frac{\partial p}{\partial x}+\frac{\partial^{2} u}{\partial y^{2}}-\frac{25}{16} M u+\alpha T \tan \left(\frac{x \cos x}{\cos \theta_{s}}\right)
\end{aligned}
$$

Persamaan Momentum sumbu- $y$

$$
\frac{\partial p}{\partial y}=0
$$

Persamaan Energi

$$
\left(\frac{\partial T}{\partial t}+u \frac{\partial T}{\partial x}+v \frac{\partial T}{\partial y}\right)=\frac{1}{\operatorname{Pr}} \frac{\partial^{2} T}{\partial y^{2}}
$$

Pada Persamaan (13) ditunjukkan bahwa Persamaan momentum tidak terpengaruh oleh variabel $y$. Sehingga tekanan alirannya hanya bergantung pada sumbu-x. Maka persamaan momentum diluar lapisan batas menjadi

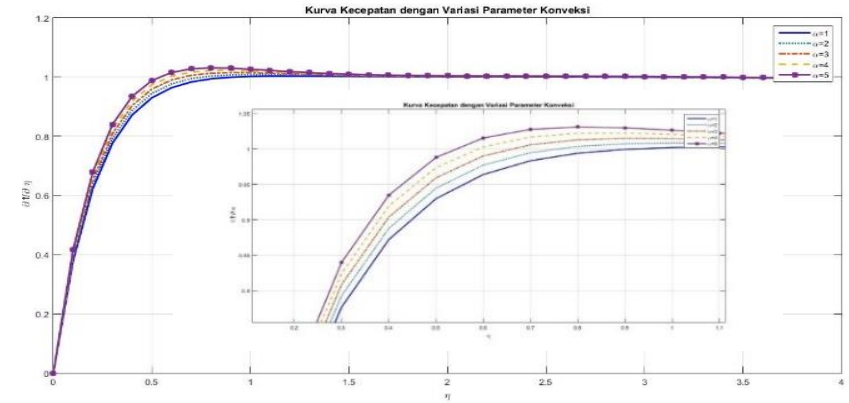

Gambar 2. Kurva Kecepatan dengan Variasi Parameter Konveksi $(\alpha)$, $\operatorname{Pr}=0.7, \theta_{s}=45^{\circ}$ dan $M=10$.

$$
\begin{aligned}
\frac{\partial u_{e}}{\partial t}+ & u_{e} \frac{\partial u_{e}}{\partial x}+v \frac{\partial u_{e}}{\partial y}= \\
& -\frac{\partial p}{\partial x}+\frac{\partial^{2} u_{e}}{\partial y^{2}}-\frac{25}{16} M u_{e}+\alpha T \tan \left(\frac{x \cos x}{\cos \theta_{s}}\right)
\end{aligned}
$$

dengan menggunakan kecepatan aliran bebas $u_{e}=$ $\frac{3}{2} \sin \left(\frac{x \cos x}{\cos \theta_{s}}\right)$ sehingga diperoleh

$$
\frac{\partial u_{e}}{\partial t}=0 \quad ; \frac{\partial u_{e}}{\partial y}=0 \quad ; \frac{\partial^{2} u_{e}}{\partial y^{2}}=0
$$

Selanjutnya disubtitusikan Persamaan (16) pada Persamaaan (15) diperoleh

$$
u_{e} \frac{\partial u_{e}}{\partial x}=-\frac{\partial p}{\partial x}-\frac{25}{16} M u_{e}+\alpha T \tan \left(\frac{x \cos x}{\cos \theta_{s}}\right)
$$

dan padasaat $T=0$ diperoleh persamaan

$$
-\frac{\partial p}{\partial x}=u_{e} \frac{\partial u_{e}}{\partial x}+\frac{25}{16} M u_{e}
$$

Kemudian kondisi $T=0$ Persamaan (18) pada Persamaan (12)

$$
\begin{aligned}
& \frac{\partial u}{\partial t}+u \frac{\partial u}{\partial x}+v \frac{\partial u}{\partial y}= \\
& u_{e} \frac{\partial u_{e}}{\partial x}+\frac{\partial^{2} u}{\partial y^{2}}-\frac{25}{16} M\left(u-u_{e}\right)+\alpha T \tan \left(\frac{x \cos x}{\cos \theta_{s}}\right)
\end{aligned}
$$

\section{E. Fungsi Alir}

Fungsi alir ini dinyatakan sebagaiberikut:

$$
u=\frac{1}{r} \frac{\partial \psi}{\partial y} \quad v=-\frac{1}{r} \frac{\partial \psi}{\partial x}
$$

Dengan mensubtitusikan pers amaan fungsi alir pada persamaan (11), (19) dan (14), maka didapat persamaan sebagaiberikut: Persamaan Kontinuitas

$$
\frac{\partial^{2} \psi}{\partial x \partial y}=\frac{\partial^{2} \psi}{\partial x \partial y}
$$

Persamaan Momentum

$$
\begin{aligned}
& \frac{1}{r} \frac{\partial^{2} \psi}{\partial t \partial y}+\frac{1}{r} \frac{\partial \psi}{\partial y} \frac{\partial^{2} \psi}{\partial x \partial y}-\frac{1}{r} \frac{\partial \psi}{\partial x} \frac{\partial^{2} \psi}{\partial y^{2}}= \\
& u_{e} \frac{\partial u_{e}}{\partial x}+\frac{1}{r} \frac{\partial^{3} \psi}{\partial y^{3}}-\frac{25}{16} M\left(\frac{1}{r} \frac{\partial \psi}{\partial y}-u_{e}\right)+\alpha T \tan \left(\frac{x \cos x}{\cos \theta_{s}}\right)
\end{aligned}
$$

Persamaan Energi

$$
\left(\frac{\partial T}{\partial t}+\frac{1}{r} \frac{\partial \psi}{\partial y} \frac{\partial T}{\partial x}-\frac{1}{r} \frac{\partial \psi}{\partial x} \frac{\partial T}{\partial y}\right)=\frac{1}{\operatorname{Pr}} \frac{\partial^{2} T}{\partial y^{2}}
$$




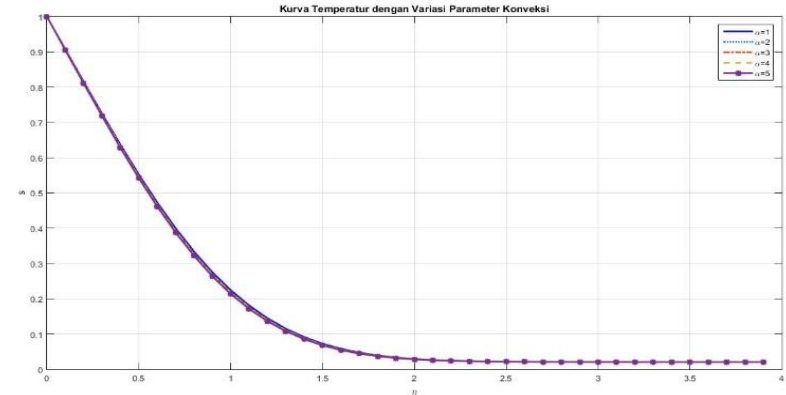

Gambar 3. Kurva Temperatur dengan Variasi Parameter Konveksi $(\alpha)$, $\operatorname{Pr}=0.7, \theta_{s}=45^{\circ}$ dan $M=10$.

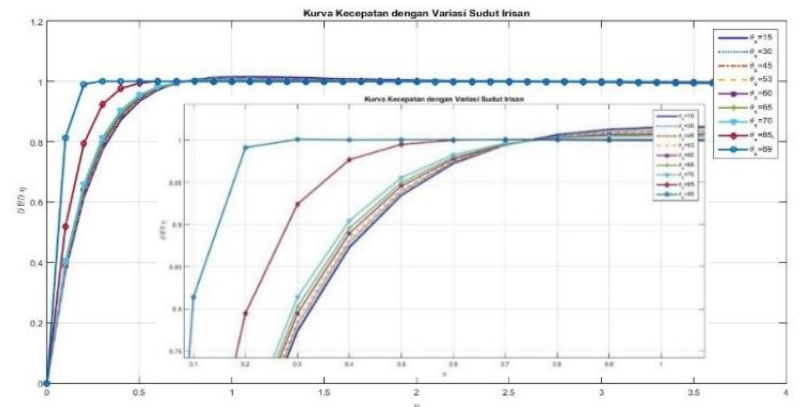

Gambar 4. Kurva Kecepatan dengan Variasi Parameter Sudut $\operatorname{Irisan}\left(\theta_{s}\right)$, $\operatorname{Pr}=0.7, \alpha=2$ dan $M=10$.

\section{F. Persamaan Similaritas}

Persamaan kontinuitas pada Persamaan (20) dapat dihilangkan dari hasil fungsi alir sehingga Persamaan pembangun hanya ada 2 yaitu persamaan momentum dan persamaan energi. Variabel similaritas untuk small time $\left(t \leq t^{*}\right)$ dengan $t^{*}$ sebarang nilai yaitu

$$
\psi=t^{\frac{1}{2}} u_{e}(x) r(x) f(x, \eta, t) \quad T=s(x, \eta, t) \quad \eta=\frac{y}{t^{\frac{1}{2}}}
$$

Sedangkan untuk large time $\left(t>t^{*}\right)$ dengan $t^{*}$ sebarang nilai yaitu

$$
\psi=u_{e}(x) r(x) F(x, Y, t) \quad T=S(x, Y, t) \quad Y=y
$$

dan pada penelitian ini sudut pengamatannya yaitu $x \approx 0$ atau dititik stagnasisehingga nilai

$$
\begin{array}{ll}
u_{e}(x) & =0 \\
\frac{\partial u_{e}}{\partial x} & =\frac{3}{2 \cos \theta_{s}} \\
\frac{\tan \left(\frac{x \cos x}{\cos \theta_{s}}\right)}{u_{e}} & =\frac{2}{3}
\end{array}
$$

kemudian dimisalkan $\frac{\partial f}{\partial \eta}=f^{\prime}$ dan $\frac{\partial s}{\partial \eta}=s^{\prime}$ untuk small time dan $\frac{\partial F}{\partial Y}=F^{\prime}$ dan $\frac{\partial S}{\partial Y}=S^{\prime}$ untuk large time

Sehingga Persamaan untuk small time menjadi

$$
\begin{aligned}
& f^{\prime \prime \prime}+\frac{\eta}{2} f^{\prime \prime}+t \frac{\partial u_{e}}{\partial x}\left[1-\left(f^{\prime}\right)^{2}+f f^{\prime \prime}\right]= \\
& t \frac{\partial f^{\prime}}{\partial t}-\frac{25}{16} M t\left(1-f^{\prime}\right)-\frac{3}{2} \alpha t s
\end{aligned}
$$

$s^{\prime \prime}+\frac{\operatorname{Pr} \eta}{2} s^{\prime}+\frac{3 \operatorname{Pr} t}{2 \cos \theta_{s}} f s^{\prime}=\operatorname{Pr} t \frac{\partial s}{\partial t}$

Dan untuk large time menjadi

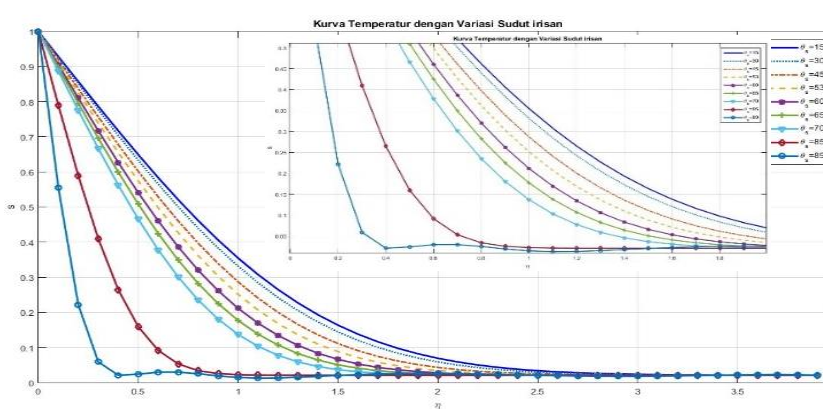

Gambar 5. Kurva Temperatur dengan Variasi Parameter Sudut $\operatorname{Irisan}\left(\theta_{s}\right), \operatorname{Pr}=0.7, \alpha=2$ dan $M=10$.

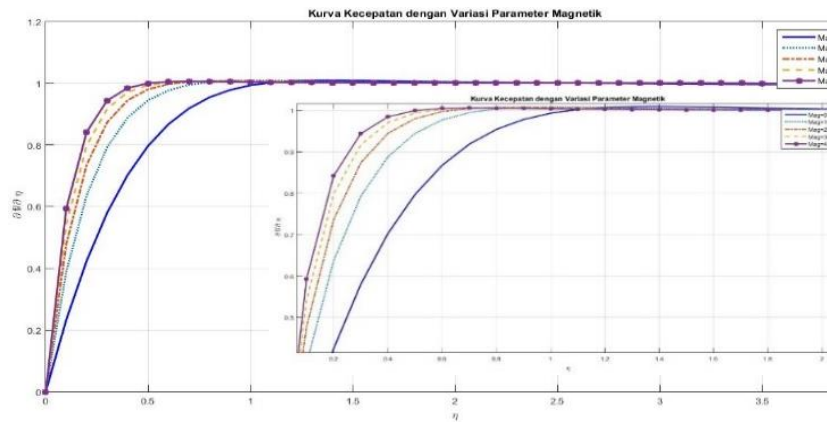

Gambar 6. Kurva Kecepatan dengan Variasi Parameter Magnetik( $M)$, $\operatorname{Pr}=0.7, \alpha=2$ dan $\theta_{s}=45^{\circ}$.

$$
\begin{gathered}
\left.F^{\prime \prime \prime}+\frac{3}{2 \cos \theta_{s}}\left[1-\left(F^{\prime}\right)^{2}+F F^{\prime \prime}\right)\right]= \\
\frac{\partial F^{\prime}}{\partial t}-\frac{25}{16} M\left(1-F^{\prime}\right)+\frac{2}{3} \alpha S \\
S^{\prime \prime}+\frac{3 \operatorname{Pr}}{2 \cos \theta_{s}} F S^{\prime}=\operatorname{Pr} S^{\prime}
\end{gathered}
$$

\section{G. Langkah-langkah Keller-Box}

1. Dilakukan proses merubah persamaan-persamaan orde tinggi menjadi persamaan-persamaan orde pertama dan melakukan permisalan fungsisebagai berikut :

$$
\begin{array}{rr}
\text { Small Time } & \text { Large Time } \\
f^{\prime}=u & F^{\prime}=U \\
f^{\prime \prime}=v & F^{\prime \prime}=V \\
s^{\prime}=q & S^{\prime}=Q
\end{array}
$$

2. Dilakukan proses diskritisasi pada model matematika yang diperoleh pada waktu kecil (Small Time) dan pada waktu besar (Large Time) menggunakan titik pusat atau titik tengah $\left(\eta_{j-\frac{1}{2}}, t^{n}\right)$ pada ruas $P_{1} P_{2}$ dengan beda hingga pusat. Sedangkan untuk persamaan-persamaan yang tak linier digunakan titik pusat atau titik tengah $\left(\eta_{j-\frac{1}{2}}, t^{n-\frac{1}{2}}\right)$ pada segi empat $P_{1} P_{2} P_{3} P_{4}$. Untuk lebih memahami pernyataan di atas lihat (Gambar 1):

3. Pada langkah ketiga dilakukan proses pelinieran persamaan-persamaan yang diperoleh dengan menggunakan metode Newton yang kemudian disajikan dalam bentuk matriks vektor. Sebelum melakukan proses pelinieran, diperkenalkan bentuk iterasi untuk metode Newton sebagaiberikut : 


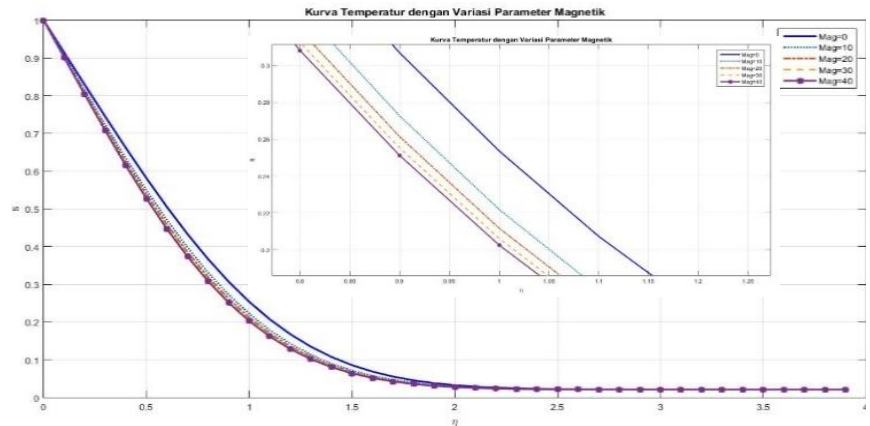

Gambar 7. Kurva Temperatur dengan Variasi Parameter Magnetik( $M)$, $\operatorname{Pr}=0.7, \alpha=2$ dan $\theta_{s}=45^{\circ}$.

$$
\begin{array}{ll}
\begin{array}{l}
\text { Small Time } \\
f_{j}^{(i+1)}=f_{j}^{(i)}+\delta f_{j}^{(i)}
\end{array} & \begin{array}{l}
\text { Large Time } \\
F_{j}^{(i+1)}=F_{j}^{(i)}+\delta F_{j}^{(i)}
\end{array} \\
u_{j}^{(i+1)}=u_{j}^{(i)}+\delta u_{j}^{(i)} & U_{j}^{(i+1)}=U_{j}^{(i)}+\delta U_{j}^{(i)} \\
v_{j}^{(i+1)}=v_{j}^{(i)}+\delta v_{j}^{(i)} & V_{j}^{(i+1)}=V_{j}^{(i)}+\delta V_{j}^{(i)} \\
s_{j}{ }^{(i+1)}=s_{j}{ }^{(i)}+\delta s_{j}^{(i)} & S_{j}^{(i+1)}=S_{j}^{(i)}+\delta S_{j}^{(i)} \\
q_{j}^{(i+1)}=q_{j}^{(i)}+\delta q_{j}^{(i)} & Q_{j}^{(i+1)}=Q_{j}^{(i)}+\delta Q_{j}^{(i)}
\end{array}
$$

4. Pada langkah keempat, hasil dari proses pelinieran diselesaikan dengan menggunakan teknik eliminasi matriks blok tridiagonal. Persamaan-persamaan dari hasil linierisasi di atas dapat diselesaikan dengan teknik eliminasi blok tridiagonal yang berupa matriks blok. Hal ini yang merupakan ciri dari penyelesaian dengan metode Keller-Box, karena pada penyelesaian dengan matriks tridiagonal, pada umumnya elemenelemennya berisi konstanta-konstanta. Hasil dari proses linierisasi tersebut dapat dibentuk matriks blok tridiagonal dengan cara dinyatakan dalam keadaan yaitu saat $j=1, j=N-1$, dan , $j=N$

\section{H. Hasil Simulasi Numerik}

Dilakukan simulasi dengan memberikan inputan beberapa variasi yaitu variasi magnetik $(M)$, variasi irisan $(\theta)$, variasi konveksi $(\alpha)$, dan variasi bilangan Prandtl pada titik stagnasi terendah yakni $x=0^{\circ}$. Dilakukan simulasi numerik bertujuan untuk mengetahui bagaimana profil kecepatan dan profil temeperatur dari pengaruh variasi berbagai kondisi.

1) Pengaruh Variasi Parameter Konveksi

Variasi parameter konveksi yang digunakan pada simulas i ini yaitu $\alpha=1,2,3,4,5$, nilai parameter lain yang digunakan adalah $M=10, \operatorname{Pr}=0,7, \theta_{s}=30^{\circ}$, banyak partisi $\eta=40$ dengan $\Delta \eta=l_{j}=0.1$ dan partisi $t=33$ dengan $\Delta t=k^{n}=$ $5 \times 10^{-2}$ dan $t=1.65$. Hasil simulasinya dapat dilihat pada (Gambar 2).

Berdasarkan Gambar 2, mulai dari $f^{\prime}=0$ sampai $f^{\prime} \approx 1$ kurva mengalami peningkatan. Dengan digunakannya variasi parameter konveksi, kecepatan mengalami peningkatan lebih signifikan sebanding dengan parameter variasi yang digun akan. Hal ini diakibatkan karena meningkatnya parameter konveksi akan meningkatkan gaya apung fluida. Gaya apung fluida akan mempengaruhi momentum fluida yang juga akan meningkatkan kecepatan fluida.

Berdasarkan Gambar 3, mulai dari $s=1$ sampai $s \approx 0$ kurva mengalami penurunan. Dengan digunakannya variasi parameter konveksi, temperatur mengalami penurunan lebih

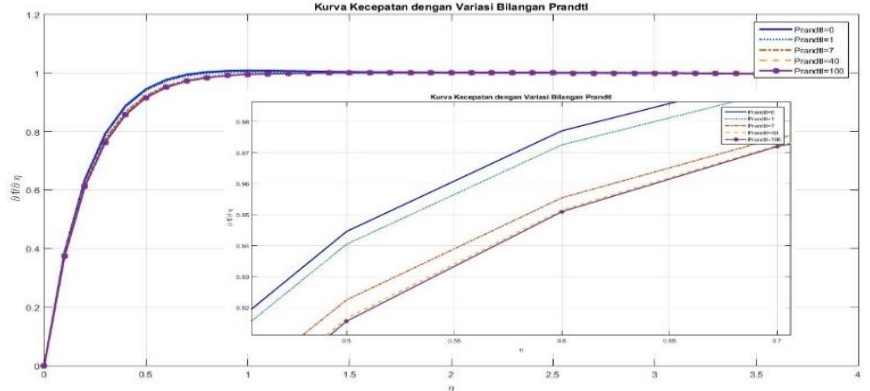

Gambar 8. Kurva Kecepatan dengan Variasi Bilangan Prandtl(Pr), dengan $\theta_{s}=45^{\circ}, \alpha=2$ dan $M=10$.

cepat dengan digunakan variasi parameter konveksi lebih tinggi. Secara matematis hal ini terjadi akibat $\alpha=\frac{G r}{R e^{2}}$. Pada $\alpha=\frac{G r}{R e^{2}}$ ditunjukan bahwa $(\alpha \sim G r)$. Bilangan Grashof sendiri dapat dinyatakan dengan $G r=\frac{g \beta\left(T_{w}-T_{\infty}\right) a^{3}}{v^{2}}$, yang berarti bahwa $\alpha \sim \operatorname{Gr} \sim\left(T_{w}-T_{\infty}\right)$. Penurunan temperatur terjadi karena $\left(T_{w}-T_{\infty}\right)$ semakin besar. Dengan $T_{w}$ nilainya tetap, maka temperatur fluida semakin kecil.

2) Pengaruh Variasi Parameter Sudut Irisan $\boldsymbol{\theta}_{\boldsymbol{s}}$

Variasi parameter sudut irisan yang digunakan pada simulas i ini yaitu $\theta_{s}=15^{\circ}, 30^{\circ}, 45^{\circ}, 53^{\circ}, 60^{\circ}, 65^{\circ}, 70^{\circ}, 85^{\circ}, 89^{\circ}$, nilai parameter lain yang digunakan adalah $M=10, \mathbf{P r}=0,7, \alpha=$ 2 , banyak partisi $\eta=40$ dengan $\Delta \eta=l_{j}=0.1$ dan partisi $t=$ 33 dengan $\Delta t=k^{n}=5 \times 10^{-2}$ dan $t=1.65$. Hasil simulasinya dapat dilihat pada (Gambar 4).

Berdasarkan Gambar 4, mulai dari $f^{\prime}=0$ sampai $f^{\prime} \approx 1$ kurva mengalami peningkatan. Dengan digunakannya variasi parameter $\theta_{s}$, kecepatan mengalami peningkatan lebih signifikan sebanding dengan parameter variasi yang digunakan. Hal ini akan sesuaijika dianalisa bahwa $\frac{3 t}{2 \cos \theta_{s}}$ pada persamaan momentum meningkat maka $\cos \theta_{s}$ semakin kecil, maka akan mengakibatkan nilai $\frac{3 t}{2 \cos \theta_{s}}$ semakin besar, sehingga momentumnya akan bertambah yang juga menyebabkan kecepatan fluida semakin meningkat.

Berdasarkan Gambar 5, mulai dari $s=1$ sampai $s \approx 0$ kurva mengalami penurunan. Dengan digunakannya variasi parameter konveksi, temperatur mengalami penurunan lebih cepat dengan digunakan variasi parameter $\theta_{s}$ lebih besar. Hal ini terjadi Karena semakin besar sudut irisan bola maka permukaan depan semakin luas yang mengakibatkan distribusi panas ke bola semakin cepat dibandingkan dengan distribusi panas fluidanya sehingga temperatur semakin menurun.

3) Pengaruh Variasi Parameter Magnetik (M)

Variasi parameter magnetik yang digunakan pada simulas i ini yaitu $M=0,10,20,30,40$, nilai parameter lain yang digunakan adalah $\alpha=2, \mathbf{P r}=0,7, \theta_{s}=30^{\circ}$, banyak partisi $\eta=40$ dengan $\Delta \eta=l_{j}=0.1$ dan partisi $t=33$ dengan $\Delta t=$ $k^{n}=5 \times 10^{-2}$ dan $t=1.65$. Hasil simulasinya dapat dilihat pada (Gambar 6).

Berdasarkan Gambar 6, mulai dari $f^{\prime}=0$ sampai $f^{\prime} \approx 1$ kurva mengalami peningkatan . Dengan digunakannya variasi parameter $\theta_{s}$, kecepatan mengalami peningkatan lebih signifikan sebanding dengan parameter variasi yang digunakan. 


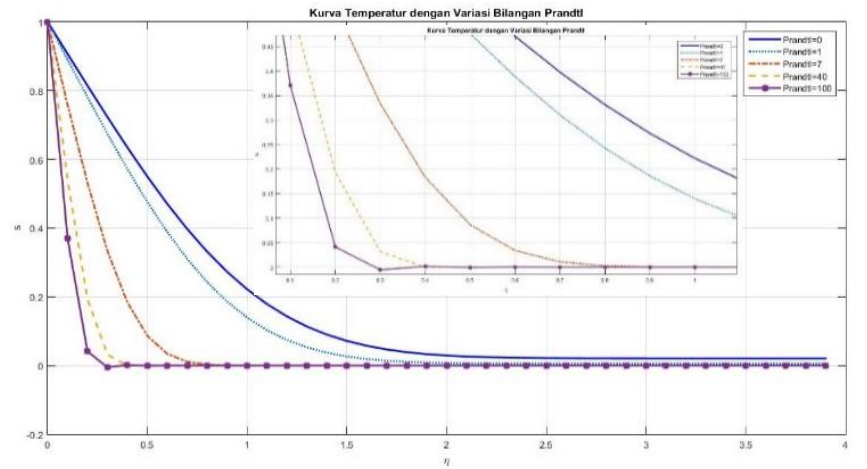

Gambar 9. Kurva Temperatur dengan Variasi Bilangan Prandtl(Pr), dengan $\theta_{s}=45^{\circ}, \alpha=2$ dan $M=10$.

Secara matematis $M=\frac{\sigma B_{0}^{2} a}{\rho U_{\infty}}$ yang berarti dengan bertambahnya medan magnet maka densitas akan berkurang sehingga hambatan akibat gaya antar partikel akan berkurang membuat kecepatan semakin bertambah.

Berdasarkan Gambar 7, mulai dari $s=1$ sampai $s \approx 0$ kurva mengalami penurunan. Dengan digunakannya variasi parameter magnetik. Hal ini terjadi karena energi internal fluida semakin bertambah karena pengaruh medan magnet dan densitas yang berkurang sebagai akibat bertambahnya parameter magnetik. Dengan bertambahnya energi internal maka energi yang digunakan fluida untuk bergerak berkurang, demikian juga dengan densitas yang berkurang artinya kerapatan molekul fluida berkurang sehingga distribusi panas antar fluida berkurang. Ini berakibat temperatur mengalami penurunan seiring bertambahnya parameter magnetik.

4) Pengaruh Variasi Bilangan Prandtl $(\boldsymbol{P r})$

Variasi bilangan Prandtl yang digunakan pada simulasi ini yaitu $\operatorname{Pr}=0,1,7,40,100$, nilai parameter lain yang digunakan adalah $\alpha=2, \mathrm{M}=10, \theta_{s}=30^{\circ}$, banyak partisi $\eta=40$ dengan $\Delta \eta=l_{j}=0.1$ dan partisi $t=33$ dengan $\Delta t=k^{n}=5 \times 10^{-2}$ dan $t=1.65$. Hasil simulasinya dapat dilihat pada (Gambar 8 ).

Berdasarkan Gambar 8 , mulai dari $f^{\prime}=0$ sampai $f^{\prime} \approx 1$ kurva mengalami peningkatan. Dengan digunakannya variasi Bilangan Prandtl temperatur mengalami penurunan lebih cepat pada Bilangan Prandtl yang semakin besar. Hal ini terjadi karena secara matematis $\operatorname{Pr}=\frac{v \rho C p}{c}$ yang berarti bahwa bilangan Prandtl sebanding dengan densitas fluida $(\mathbf{P r} \sim \rho)$. Jadi jika bilangan Prandtl bertambah maka densitas fluida semakin meningkat. Sehingga hal inilah yang mengakibatkan kecepatan fluida mengalami penurunan seiring dengan bertambahnya bilangan Prandtl.

Berdasarkan Gambar 9, mulai dari $s=1$ sampai $s \approx 0$ kurva mengalami penurunan. Dengan digunakannya variasi parameter magnetik, temperatur mengalami penurunan lebih cepat sebanding dengan bilangan Prandtl yang semakin besar. Jika diamati dengan variasi bilangan Prandtl, kurva temperatur semakin menurun dengan bertambahnya bilangan Prandtl. Hal ini terjadi karena $\operatorname{Pr}=\frac{v \rho C_{p}}{c}$ yang artinya bilangan Prandtl merupakan perbandingan viskositas kinematika dengan difusivitas termal. Viskositas kinematika berkaitan dengan kecepatan perpindahan antara molekul, sedangkan difusivitas termal berkaitan dengan perbandingan penerusan pan as dengan kapasitas penyimpanan energi molekul. Semakin besar bilangan Prandtl mengakibatkan difusivitas termal semakin kecil karena bilangan Prandtl berbanding terbalik dengan difusivitas termal. Ini berarti bahwa dengan bertambahnya bilangan Prandtl maka distribusi panas antar fluida berkurang atau dapat dikatakan perpindahan panas ke permukaan benda lebih cepat dari pada fluidanya sehingga mengakibatkan temperatur fluida semakin menurun dengan bertambahnya bilangan Prandtl.

\section{KESIMPULAN}

Dari hasil analisis dan pembahasan yang telah dilakukan, sehingga dapat disimpulkan sebagai berikut:

Berdasarkan analisis, pembahasan, serta simulasi numerik dari magnetohidrodinamik yang tak tunak pada lapisan batas yang mengalir melalui bola teriris di dalam fluida kental di bawah pengaruh medan magnet, maka dapat disimpulkan bahwa parameter magnetik $(M)$, parameter konveksi $(\alpha)$, besar sudut irisan bola $\left(\theta_{\mathrm{s}}\right)$, dan bilangan Prandtl berbanding lurus dengan kecepatan fluida. Sedangkan, parameter magnetik $(M)$, parameter konveksi $(\alpha)$, bes ar sudut iris an bola $\left(\theta_{\mathrm{s}}\right)$ berbanding terbalik dengan temperatur fluida, dan bilangan Prandtl berbanding lurus dengan temperatur fluida.

\section{DAFTAR PUSTAKA}

[1] B. Widodo, D. A. Khalimah, F. D. S. Zainal, and C. Imron, "Numerical Solution of Heat Transfer Unsteady Boundary Layer Magnet ohydrodynamics in Micropolar Fluid Past a Sphere," Int. J. Far East J. Math. Sci. Publ. House-India, 2015.

[2] S. Irianto, "Kombinasi Operasi PLTU - MHD - Fuel Cell Dan Kemungkinan Penerannya Di Indonesia," Institut Teknologi Sepuluh Nopember, 2013.

[3] P. A. Davidso, An Introduction to Magnetohydrodynamics. New York: Cambridge University Press, 2010.

[4] I. G. E. P Wijaya, "Magnetohidrodinamik Fluida Kental Tak Tunak dengan Konveksi Paksa yang Mengalir Melewati Bola Teriris," Institut Teknologi Sepuluh Nopember, 2016.

[5] D. . Khalimah, "Analisa Aliran Tak Tunak Konveksi Paksa Fluida Kental Magnetohidrodinamik (MHD) Melewati Silinder Eliptik," Institut Teknologi Sepuluh Nopember, 2015.

[6] B. Widodo, C. Imron, and R. Sahaya, "Aliran Fluida Magnetohidrodinamik Viskoelatis Tersuspensi yang Melewati Pelat Datar," J. Sains dan Seni ITS, vol. 5, no. 2, 2016.

[7] B. Widodo, D. A. Khalimah, F. D. S. Zainal, and C. Imron, "The Effect of Prandtl Number and Magnetic Parameter on Forced Convection Unsteady Magnetohydrodynamic Boundary Layer Flow Of A Viscous Fluid Past A Sphere," in International Conference on Science and Innovative Engineering (ICSIE), 2015.

[8] B. Widodo, C. Imron, N. Asiyah, G. O. Siswono, T. Rahayuningsih, and Purbandini, "Viscoelastic Fluid Flow Pass A Porous Circular Cylinder When The Magnetic Field Included," J. Math. Sci., vol. 99, no. 2, pp. 173-186, 2016.

[9] B. Widodo, I. Anggriani, D. . Khalimah, F. D. S. Zainal, and C. Imron, "Unsteady Boundary Layer Magnetohydrodynamics In Micropolar Fluid Past A Sphere," Far East J. Math. Sci., vol. 2, pp. 291-299, 2016. 